\title{
Taxing sugar
}

\section{(ब) (1) $\Theta$ OPEN ACCESS}

\section{An old idea with a new place in the fight against obesity?}

\author{
Franco Sassi head \\ OECD Public Health Programme, Health Division, Organisation for Economic Co-operation and Development, 75016 Paris, France
}

A staggering growth of obesity rates in countries worldwide has left governments and other stakeholders scrambling for effective solutions. ${ }^{12}$ Few countries so far have gone beyond mild actions in tackling obesity, unhealthy diets, and physical inactivity; all major triggers of the current epidemic of non-communicable diseases. Yet the economic crisis has heightened concerns about the long term sustainability of healthcare systems. At any time an obese person incurs at least $30 \%$ higher medical expenditures than someone of a healthy weight. ${ }^{3}$ Fiscal measures have a legitimate place in the public health policy toolkit, ${ }^{4}$ and several countries have chosen to use taxes on foods and non-alcoholic beverages in an attempt to improve the quality of people's diets and curb the spread of obesity. ${ }^{5}$ Mexico was one of the latest to join this group, when in 2014 it launched a comprehensive strategy to fight an obesity problem that has reached extraordinary proportions. The Organisation for Economic Co-operation and Development and World Health Organization had estimated in 2010 that a similar strategy could save about 160000 disability adjusted life years in Mexico annually. ${ }^{1}$ Mexico is also one of the top consumers of sugar worldwide, as well as a top producer and exporter. ${ }^{6}$ The strategy includes taxes on sugar sweetened beverages and on calorie dense foods. ${ }^{\text {? }}$

In a linked paper, Colchero and colleagues report the first, much anticipated, empirical evaluation of the early impacts of

Mexico's excise tax on sugar sweetened beverages. ${ }^{8}$ The study is not based on the estimation of a full demand system, which we may expect to see in the future, but on a pragmatic difference in differences approach, relative to a counterfactual extrapolated from past trends. Purchases of taxed beverages in urban areas in Mexico declined more than expected (on average 4.2 fewer litres per year, or $6 \%$ of all purchases of taxed beverages), while purchases of untaxed beverages increased (12.8 litres more than the counterfactual). Reductions in purchases of sugar sweetened beverages were larger and increased over time for consumers of lower socioeconomic status.

These results are not surprising, but their empirical confirmation is of the greatest importance for governments that have opted to use taxes on sugar sweetened beverages as part of public health strategies, and those considering to do it. The study helps us to look beyond the ideological statements that tend to dominate the public debate. Consumers do respond to price changes that taxes can produce, and this new study contributes to a large evidence base. ${ }^{9}$ But other outcomes are not fully explored. Whether consumers' reactions will lead to healthier diets depends on how taxes are designed and what selection of products they target. Despite evidence of an increase in purchases of untaxed beverages, especially bottled water, the full extent of substitutions made by Mexican consumers is not known. We also do not know from the study whether a 1 peso/L tax is large enough to achieve meaningful health benefits. To assess this, population models are needed..$^{10}$

Taxes are not simple tools, and designing them to engineer an improvement in people's diets is especially complex. Setting them at sufficiently high levels is politically challenging, and increases the risk of unintended consequences. Taxes can be part of a public health strategy - and Mexico's is a great example for other countries-but they cannot be viewed as a magic bullet in the fight against obesity. The claim that sugar is an ideal candidate for taxation dates back at least to Adam Smith's work on the "wealth of nations" in the 18th century, but for taxes on products containing sugar to improve population health, more conditions have to be met than Adam Smith could have envisaged, and complementary actions have to be put in place. The single most valuable contribution taxes can make to a public health strategy is the signal they give consumers and the entire food system ("from farm to fork"), that a government is concerned about the harms associated with unhealthy diets and is serious about tackling them. This is the strongest incentive for consumers to reconsider choices often made automatically, based on habits or environmental influences, and for players in the food supply chain to reorient their production towards healthier options.

But other, complementary, policies are also needed. A broad menu includes regulatory measures (for example, nutrition labelling, regulation of health claims, and advertising), health education based on a sound behavioural understanding of consumers' food choices, incentives for research and 
development in food production, voluntary initiatives with agreed targets and independent monitoring, changes in the environment of food choice, and counselling by general practitioners of people at higher risk. Taxes do have a place in a broader strategy in countries that are facing disproportionate harms from unhealthy diets, but having to make people pay for their potentially unhealthy consumption choices is not a success for public health. If all of the above policies were used systematically and effectively, the focus of the policy debate might shift away from taxes in the future.

The opinions expressed and arguments employed in this editorial are those of the author. They do not represent the official views of the OECD or of its member countries.

Competing interests: I have read and understood the BMJ policy on declaration of interests and declare the following: none.

Provenance and peer review: Commissioned; not peer reviewed.

1 Sassi F. Obesity and the economics of prevention. Fit not fat. OECD Publishing, 2010doi: $10.4337 / 9781849808620$.

2 Sassi F, Devaux M, Cecchini M. Obesity. In: Scheffler R, ed. Handbook of global health economics and public policy. World Scientific 2016 (In press).
3 Withrow D, Alter DA. The economic burden of obesity worldwide: a systematic review of the direct costs of obesity. Obes Rev 2011;12: 131-41. doi:10.1111/j.1467-789X.2009. 00712.x 20122135

4 Sassi F, Belloni A, Capobianco C, Alemanno A. Taxation and economic incentives. In: Alemanno A, Garde A, eds. Regulating lifestyle risks-the EU, alcohol, tobacco and unhealthy diets. Cambridge University Press, 2014doi:10.1017/CBO9781107478114. 008.

5 OECD obesity update 2012. OECD Publishing, 2012. www.oecd.org/health/49716427. pdf.

$6 \mathrm{OECD} /$ Food and Agriculture Organization of the United Nations. OECD-FAO agricultural outlook. OECD Publishing, 2015.

7 OECD obesity update 2014. OECD Publishing, 2014. www.oecd.org/health/ObesityUpdate-2014.pdf.

8 Colchero MA, Popkin BM, Rivera JA, Ng SW. Beverage purchases from stores in Mexico under the excise tax on sugar sweetened beverages: observational study. BMJ 2015; 351:h6704. 10.1136/bmj.h6704.

9 Hawkes C, Sassi F. Tackling unhealthy diets. In: McDaid D, Sassi F, Merkur S, eds. Promoting health, preventing disease: the economic case. Open University Press, 2015

10 Legetic B, Cecchini M, eds. Applying modeling to improve health and economic policy decisions in the Americas: the case of noncommunicable diseases. Pan American Health Organization, 2015. http://dx.doi.org/10.1787/9789264243606-en.

Published by the BMJ Publishing Group Limited. For permission to use (where not already granted under a licence) please go to http://group.bmj.com/group/rights-licensing/ permissions

This is an Open Access article distributed in accordance with the Creative Commons Attribution Non Commercial (CC BY-NC 3.0) license, which permits others to distribute, remix, adapt, build upon this work non-commercially, and license their derivative works on different terms, provided the original work is properly cited and the use is non-commercial. See: http://creativecommons.org/licenses/by-nc/3.0/. 